\title{
AN AMERICAN DILEMMA: THE FLOW OF TRADE VERSUS THE FLOW OF PEOPLE IN NAFTA
}

\author{
Emilio C Viano*
}

\section{ABSTRACT}

The North American Free Trade Agreement (NAFTA) of 1994 aims at creating the legal, political, and business conditions for a freer circulation of goods, capitals and services in North America. However it gives scant attention to the mobility of workers.

The basic premise of this paper is that globalisation of trade and the universal diffusion of human rights have evolved and progressed side by side, even though with difficulty and reluctantly, and that the regional liberalisation of trade must be deeply interwoven with issues related to socio-economic rights to be ultimately and durably successful.

This paper's major questions are: How does NAFTA address labour mobility? Does NAFTA neglect, oppose or support the free movement of people across its borders? Does the agreement deal with labour mobility in a clear and definite manner or does it ignore it and give it short shrift? Should NAFTA support the liberalisation of immigration within its area as a long term objective, as part of a deeper and broader regional integration, conditioned on considerable reforms by its Member States, especially Mexico's legal system, and energy, tax and banking policies, among others? Is the free movement of people needed to be truly successful and provide economic security, survival and prosperity for its member countries in view of vastly changed economic and trade conditions since its inception?

This paper first traces the history of the drafting of NAFTA. Then it examines what NAFTA means for labour mobility within the complex interaction between an economic colossus like the United States and a developing country like Mexico, also taking into account current migration trends. In this section, the paper also covers the liberalisation of the mobility of labour (albeit limited) brought about through administrative regulations. Interspersed with this there is a discussion of what should be a mutually reinforcing relationship between international free trade and social policy.

\footnotetext{
* LLB (Hons), LLM (Leicester; Washington College of Law: Law and Government and International Legal Studies), MA, PhD (New York University).
} 


\section{AN AMERICAN DILEMMA: THE FLOW OF TRADE VERSUS THE FLOW OF PEOPLE IN NAFTA}

Then the paper addresses the links and the relationship between trade, labour standards and migration. Comparative perspectives with the approach of the European Union to movement of workers are also included. Finally, there is a brief critique evaluating NAFTA's legal processes against the ideal to reconcile social integration with regional free trade. Economic realities and crises and the surge in economic and trade power of China, India and possibly Brazil that are redefining the pre-eminence and dominance of the United States are also factored in when the argument for liberalisation of the movement of people within NAFTA is made.

\section{INTRODUCTION}

When Canada, Mexico and the United States completed the negotiations for the North America Free Trade Agreement ${ }^{1}$ (NAFTA), Gene McNary, the then Immigration and Naturalization Service (INS) Commissioner, stated that:

"[I] feel more than a bit confident in acknowledging that, if immigration is not formally on the table, someone of the table will sooner or later realise as a practical matter that moving goods and services in international commerce also involves moving the people who trade in those goods and services."2

\footnotetext{
1 The North American Free Trade Agreement, Dec 17, 1992, US-Can-Mex, 32 I L M 289 (Parts 1-3) and 32 I L M 612 (Parts 4-8) [hereinafter NAFTA]. The North American Free Trade Agreement is a free trade agreement between Canada, the United States of America and Mexico. It was initially pursued by free-trade conservative governments in the United States and Canada, led by Canadian Prime Minister Brian Mulroney, and US President George H W Bush. There was considerable opposition on both sides of the border. In the United States President Clinton made its passage a major legislative initiative and was able to secure passage in 1993. Vice President Al Gore attempted to build support for the bill by debating the issue with H Ross Perot on the Larry King Live talk show. Perot was an outspoken critic of NAFTA during his 1992 presidential campaign, claiming that passage would cause a "giant sucking sound" of jobs leaving the United States for Mexico. After intense political debate, and the negotiation of several side agreements, the US House passed NAFTA by 234-200 (132 Republicans and 102 Democrats voting in favour) and the US Senate passed it by 61-38. Some opposition persists to the present day. NAFTA was signed on December 17, 1992 and went into effect on January 1, 1994.

2 See Noemi Gal-Or "Labour Mobility Under NAFTA: Regulatory Policy Spearheading the Social Supplement to the International Trade Regime” (1998) 15 Arizona Journal of International and Comparative Law 365. See also Gene McNary "Making Goods and People in International Commerce: Remarks of the Hon Gene McNary” (1992) 2 Duke Journal of Comparative and International 247.
} 
When considered by itself, the above statement may simply express the frustration of the (then) INS $^{3}$ seeing immigration issues marginalised during the setting up of the first major trade agreement in North America. However, when it is considered in the context of the discussions at that time, during which organised labour, environmental and other non-governmental organizations (NGO) and interest groups were voicing their concern, disagreements and disappointment, it represents a substantial issue in its own right. Actually, labour unions were not fighting for the right of freedom of movement for people, that is for labour mobility across the NAFTA territory as a right for each worker, but, on the contrary, were concerned about the migration of factories and other business away from American workers. In particular they were worried about the flight of business away from low skilled and lower socioeconomic level labour in the United States and Canada towards Mexicans. They were very concerned that Mexican immigrants in the US would take away jobs currently being filled by American workers and drive down wage rates in those sectors where Mexican workers were competing for jobs in the US. ${ }^{4}$ This is still the root of the unions' opposition to allowing Mexican lorries with Mexican drivers to carry cargo to and from the US. Additional areas of contention were the protection and harmonisation of labour rules and the concern that they may be downgraded as the outcome of joining two developed economies with a developing one.

Historically, there has been considerable resistance in the United States to recognising socio-economic rights. Almost exclusive preference has been given to civil and political rights. This is evidenced by the fact that the United States has ratified the UN Covenant on Civil and Political Rights but not that on Economic, Social and Cultural Rights. ${ }^{5}$ In addition the two march in unison: while the labour standards do not per se affect labour mobility, labour mobility includes issues related to labour standards. An example is providing the same protections to non-nationals as to nationals.

Even its proponents thought of NAFTA not as a customs union or a single market but only as a free trade area similar to its predecessor, the Canada-

\footnotetext{
${ }^{3}$ Now part of the US Department of Homeland Security, and called the US Customs and Border Protection (CBP).

4 Patricia Fernandez-Kelly "NAFTA and Beyond: Alternative Perspectives in the Study of Global Trade and Development" (2007) The Annals of the American Academy of Social and Political Sciences 610.

5 Both Covenants were adopted by the UN General Assembly, Resolution 2200, December 16, 1966. The ICCPR came into force on March 24, 1976. The US Senate gave its "advice and consent" for ratification in June 1992 but with numerous and substantial reservations and exceptions. The ICESC came into force on January 3, 1976. The US has not ratified it.
} 


\section{AN AMERICAN DILEMMA: THE FLOW OF TRADE VERSUS THE FLOW OF PEOPLE IN NAFTA}

United States Free Trade Agreement (FTA). ${ }^{6}$ NAFTA did not include any plans for political and social integration. For this reason many analysts maintain that NAFTA was not conceived with the goal of establishing a system that allowed the freedom of movement of persons between the three member states. Rather it was thought of as expressly facilitating only the movement of goods, capital and services. People and their freedom of movement are noticeably excluded. ${ }^{7}$ Chapter 16 is designed to facilitate temporary visitors for business, but certainly not the workers' movement. The fact that immigration issues were not discussed or considered at that time demonstrates the high awareness and sensitivity felt around this issue. ${ }^{8}$ It is specifically because of the high volatility of immigration issues in the relations between the United States and Mexico ${ }^{9}$ that the Parties to the treaty decided to avoid it for fear of endangering agreement on the "directly related (real) trade issues" being negotiated at that time. ${ }^{10}$ Efforts to address labour mobility would certainly have led to the rejection of NAFTA in the Congress

${ }^{6}$ (1988) 27 International Legal Materials 29 [KJ5 I574]. Public Law 100-449 (Act of 9/28/88); see also United States-Canada Free-Trade Agreement Implementation Act of 1988 (Public Law 100 - 449, 102 Stat 1851); Executive Order 12662, Implementing the United States-Canada Free-Trade Implementation Act, December 31, 1988. The Free Trade Agreement (FTA) was a trade agreement reached by Canada and the United States in October 1987. The agreement removed several trade restrictions in stages over a ten year period, and resulted in a great increase in crossborder trade. On January 1, 1994, it was superseded by the North American Free Trade Agreement, which included Mexico as well.

${ }^{7}$ See Elizabeth Kraus "The Systemic Effects of Economic Trade Zones on Labour Migration: The North American Free Trade Agreement and the Lessons of the European Community” (1993) 7 Georgetown Immigration Law Journal 323. See also Kevin Johnson "Free Trade and Closed Borders: NAFTA \& Mexican Immigration in the United States” (1994) 27 UC Davis Law Review 937.

${ }^{8}$ See Beverly Baker-Kelly “United States Immigration: A Wake-Up Call!” (1994) 37 Howard Law Journal 283. See also Bradly J Condon and J Brad McBride "Do You Know the Way to San José? Resolving the Problem of Illegal Mexican Migration to the United States” (2003) 17 Georgetown Immigration Law Journal 251.

${ }^{9}$ See Luis Herrera-Lasso "The Impact of US Immigration Policy on US-Mexico Relations” (1998) 3 UCLA Journal of International Law \& Foreign Affairs 357.

${ }^{10}$ For a discussion of how and why US-Mexico immigration and trade policies have developed independently, see Gabriela A Gallegos "Borders Matter: Redefining the National Interests in US-Mexico Immigration and Trade Policy" (2004) 92 California Law Review 1729. Gallegos argues that "the separation of trade and immigration likely stems not simply from economic rationales, but from an understanding of the national interest grounded in nativistic racism...” at 1729. See also D Massey, J Durand and N J Malone Labor Economics: Beyond Smoke and Mirrors: Mexican Immigration in an Era of Economic Integration (New York: Russell Sage Foundation, 2002). 
and Senate. ${ }^{11}$ Migration issues were as politically sensitive in the early 1990s as they are today but the number of Mexican workers in the US then (legally and illegally) was far lower than it is today.

Even though immigration between Canada and Mexico has been limited ${ }^{12}$ and between Canada and the United States not problematic, the Canadians were concerned about this matter as well. ${ }^{13}$ Historically, both Canada and the United States have linked the importation of labour with granting citizenship. Even though Canada grants temporary working permits and gives those who qualify a working visitor status, this is not the norm. Likewise, the United States, with the considerable exception of Mexican migrant farm workers, until at least the 9/11 events preferred permanent residence and now naturalization to issuing working permits. ${ }^{14}$ Because of increased deportations post 9/11 for various reasons, especially for a past criminal record, regardless of how slight and ancient the crime, many immigrants have decided to apply for citizenship as an added protection against possible deportation proceedings. ${ }^{15}$ President Bush's 2004 proposal to create, expand and formalize a guest worker program ${ }^{16}$ was rejected by the Republican

${ }^{11}$ Patricia Fernandez-Kelly and Douglas S Massey "Borders for Whom? The Role of NAFTA in Mexico-US Migration” (2007) 610 Annals 98.

12 See Gal-Or, above n 3, at 366. For a comprehensive discussion of Canada-Mexico relations on issues of immigration and NAFTA, see D Goldfarb The Canada-Mexico Conundrum: Finding Common Ground (Toronto: Howe Institute, 2005).

13 The number of legal, temporary workers in Canada from Mexico rose 68 percent, to 22,344 from 13,261, from 1998 to 2003. By comparison, there were 110,075 legal, temporary workers admitted to the United States from Mexico in 1998, and 130, 327 in 2003, an 18 percent rise. The number of Mexicans legally resident in Canada is only about 50,000 while in the millions in the United States.

${ }^{14}$ See Shannon Leigh Vivian "Be Our Guest: A Review of the Legal and Regulatory History of US Immigration Policy Toward Mexico and Recommendations for Combating Employer Exploitation of Non-Immigrant and Undocumented Workers" (2005) 30 Seton Hall Legislative Journal 188.

${ }^{15}$ For example, in FY 2004, 537,151 people gained US citizenship, yet a processing backlog of 653,190 naturalization applications remained. The number of naturalizations was a 16 percent increase from the 463,204 naturalized in FY 2003. The higher naturalization numbers were consistent with the higher number of applications received during FY 2004. The processing backlog grew 4 percent $(25,920)$ between FY 2003 and FY 2004. See:

http://www.migrationpolicy.org/pubs/FS12_immigration_US_2005.pdf

${ }^{16}$ See Ryan D Frei "Reforming US Immigration Policy in an Era of Latin American Immigration: The Logic Inherent in Accommodating the Inevitable” (2005) 39 University of Richmond Law Review 1355 (2005). See also Pia Orrenius and Madeline Zavodny "Immigration Policy: What are the Consequences of an Amnesty for 


\section{AN AMERICAN DILEMMA: THE FLOW OF TRADE VERSUS THE FLOW OF PEOPLE IN NAFTA}

dominated Congress that instead adopted legislation meant to stop Mexican illegal immigration through the construction of a wall, sensors and other security measures along the US-Mexican border. ${ }^{17}$

However, as this paper will attempt to illustrate, the Canada-US Free Trade Agreement of 1989 (CUSFTA) and subsequently NAFTA, have brought forth modest changes in the prevailing norm of exclusion by introducing and identifying those in the service sector crossing NAFTA boundaries as in a "guest worker" category. These visas to the US, however, are quite difficult to obtain.

The basic premise of this paper is that globalisation of trade and the universal diffusion of human rights have evolved and progressed side by side, even though with difficulty and reluctantly, and that the regional liberalisation of trade should be deeply interwoven with issues related to socio-economic rights. ${ }^{18}$ Generally, the justification and the objectives of a regional trade agreement are the development and strengthening of trade relations among the parties and, at least for the US, encouraging economic development and respect for the rule of law. This normally involves and affects political systems where labour management issues constitute an integral part of the socio-economic fabric. In this case any separation of these different components can be only temporary and forced. Of course, "temporary" can be a very long time, especially when one is discussing immigration. Outside the European Union, there are almost no FTAs that provide for any significant degree of labour mobility. The movement of persons, except for professionals, has not been successfully addressed not even in the General Agreement on Trade in Services (GATS).

Thus, this paper's basic questions are: How does NAFTA address labour mobility? Does NAFTA neglect, oppose or support the free movement of people across its borders? Does the agreement deal with labour mobility in a clear and definite manner or does it ignore it and give it short shrift? Should the free movement of people be a long term objective of NAFTA, as part of a deeper and broader regional integration, conditioned on considerable reforms

Undocumented Immigrants?” (2004) 9 Georgetown Public Policy Review 21. See also above $n 9$.

${ }^{17}$ HR 6061 Secure Fence Act 2006, 109th Congress, 2nd Session. See Justin C Glon, "Good Fences Make Good Neighbors: National Security and Terrorism - Time to Fence In Our Southern Border” (2005) 13 Indiana International and Comparative Law Review 349; Michael J Mayerle "Proposed Guest Worker Statutes: An Unsatisfactory Answer to a Difficult, it not Impossible Question” (2002) 6 Journal of Small \& Emerging Business Law 559.

18 See Zoe Lofgren "Globalization, Security \& Human Rights: Immigration in the 21st Century: A Decade of Radical Change in Immigration Law” (2005) 6 Stanford Law \& Policy Review 349. 
by its Member States, especially Mexico's legal system, and its energy, tax and banking policies among others? If one looks only at NAFTA's direct effects on the liberalisation of the movement of people, then the answer is quick and short: none at all. However, this paper will also address the indirect effects where there is a good deal to discuss.

It is this paper's position that NAFTA was conceived as a strategic superstructure that provided a detailed treatment in the areas of trade in goods, trade in services, investment, intellectual property and dispute settlements, among others. Some of the main actors, like former Mexican president Vicente Fox, saw the agreement six years after its entry into force as a basis for a wider and deeper integration, involving workers' movement as well as other issues. However, Fox found little sympathy and support for his objectives from Canada and the US. The NAFTA process functions at different levels, reflecting the major players in it. There are the federal governments of the three countries that negotiated and signed the treaty and agreed upon the general framework of the agreement; and then, their constituent units, the States in the United States ${ }^{19}$ and Mexico and the provinces in Canada, charged with some of the implementation and application of the agreement. Most of the implementation is at the federal level, although in some areas (for example, investment and services) the states or provinces play a major role. Among the states, those at the frontier with Mexico play an even more significant role in migration issues. However, there is little formal coverage of such issues in NAFTA as already noted earlier. State and provinces also act as liaison between the federal and the local levels; and the bodies regulating labour reflect their own interpretation of NAFTA and thus play a major role in the continuous interpreting and drafting process that may additionally open up the regime to the free movement of people. ${ }^{20}$

\footnotetext{
19 There is considerable tension between States and the United States on the issue of who should be paying for the costs of illegal immigration (eg public benefits, education, medical care, law enforcement and incarceration). Data show that Florida, California, New Jersey, New York, Illinois and Texas have felt a negative economic impact because of illegal immigration. The US Supreme Court denied certiorari to Florida's claim for federal reimbursement. See ARE THESE CASES? PLEASE CLARIFYChiles, 874 F Supp 1334, 1342 (SD Fla 1994); Chiles, 69 F 3d. 1094, 1097 $\left(11^{\text {th }}\right.$ Cir 1995); Padavan, 82 F 3d 23, 28-29 (2 ${ }^{\text {nd }}$ Cir 1996); New Jersey, 91 F. 3d 463467 ( $3^{\text {rd }}$ Cir 1996). Many States argued $10^{\text {th }}$ Amendment violations ("a commandeering of state legislative processes") based on New York v US, 505 US 144, 161 (1992). See also Stephen H Legomsky, "Immigration, Federalism, and the Welfare State” (1995) 42 UCLA Law Review 1453; Richard Sybert "Population, Immigration and Growth in California” (1994) 31 San Diego Law Review 945. See Gal-Or, above n 3, at 368.

20 James F Hollifield and Thomas Chang "Trade and Migration in North America: The Role of NAFTA” (2005) 11 Law \& Business Review 327, at 336.
} 
Mobility is a highly complex area that ranges from laws regulating immigration to recognition of university and training credentials to the right to practice one's profession in a different country. ${ }^{21}$ Consequently labour unions and professional organizations play a major role in facilitating and promoting the free circulation of persons. Introducing and strengthening regional and international free trade interwoven with the corresponding and commensurate social policy is indeed a complex process. ${ }^{22}$

This paper first traces the history of the drafting of NAFTA. Then it examines what NAFTA means related to labour mobility within the complex interaction between an economic colossus like the United States and a developing country like Mexico, also taking into account current migration trends. In this section, the paper also covers the liberalisation of the mobility of labour (albeit limited) brought about through administrative regulations. Interspersed with this there is a discussion of what should be a mutually reinforcing relationship between international free trade and social policy. Then the paper addresses the links and the relationship between trade, labour standards and migration. Comparative perspectives with the approach of the European Union to movement of workers are also addressed. Finally, there is a brief critique evaluating NAFTA's legal processes against the ideal to reconcile social integration with regional free trade. Economic realities and crises and the surge in economic and trade power of China, India, possibly Brazil that are redefining the pre-eminence and dominance to date of the United States are also factored in, when the argument for liberalisation of the movement of people within NAFTA is made.

\section{THE HISTORY OF THE AGREEMENT}

Within the framework of the continuous worldwide process of building trade blocks, the United States, Canada and Mexico came to realise in the late 1980s-early 1990s how important it is to enter into regional agreements that reflect the interests and the aspirations of the contracting parties. The main impetus for the creation of NAFTA came from Canada. After the Second World War, Canada actually preferred the multilateral atmosphere because of the need to assert and protect Canada's sovereignty opposite its powerful southern neighbour, the United States. However, growing globalisation, the new trade realities introduced by the World Trade Organization, and the changing economic climate pressured Canada to review its relationship with its most important trading partners and to restructure them accordingly by

21 Kevin R Johnson "Free Trade and Closed Borders: NAFTA and Mexican Immigration in the United States” (1994) 27 UC Davis Law Review 937, at 944.

22 See Philip Martin “NAFTA and Mexico-US Migration: Policy Options” (2004) 11 Law and Business Review of the Americas 361, at 372. 
preferring bilateral agreements. ${ }^{23}$ It is worth pointing out that the US had changed its own policy of favouring only trade liberalisation in Geneva in the mid 1980s, when it negotiated an FTA with Israel. There was also a partial precedent in the 1965 bilateral agreement on autos and auto parts between Canada and the United States, covering a sector that still accounts for a huge percentage of total North American trade in industrial goods. ${ }^{24}$

It was Canada that initially proposed the Free Trade Agreement ${ }^{25}$ with the United States and paved the way to it. The FTA was a very controversial issue in Canada, with many fearing economic, cultural and political domination by the United States. It attracted almost no attention in the United States. In formulating the agreement, the Canadians did favour the sectoral free trade approach to trade liberalisation. ${ }^{26}$ Even though this at the end was politically rejected, remnants of the sectoral approach continue to be embedded in the subsequent treaty, NAFTA. A good example is the labour market where a clear and sharp distinction is drawn between high skilled and low skilled labour. ${ }^{27}$ This in turn impacts the freedom of movement across the NAFTA. For example, Chapter 14 on Trade and Services of the CUSFTA ${ }^{28}$ began a trend of also covering services in trade agreements. ${ }^{29}$ Admittedly it

${ }^{23}$ See B W Wilkinson "NAFTA in The World Economy: Lessons and Issues for Latin America” in R G Lipsey and P Meller (eds) Western Hemisphere Trade Integration: A Canadian-Latin American Dialogue (London: Macmillan Press, 1997).

24 In 1964, only seven percent of vehicles made in Canada were sent south of the border, but by 1968, thanks to the Automotive Products Trade Agreement, commonly known as the Auto Pact or APTA, an important trade agreement between Canada and the United States signed by Prime Minister Lester B Pearson and President Lyndon B Johnson in January 1965, this was sixty percent. By the same date, 1968, forty percent of cars purchased in Canada were made in the United States. Automobile and parts production quickly surpassed pulp and paper to become Canada's most important industry. Canada's trade deficit was reversed into a trade surplus worth billions of dollars annually to Canada. The APTA was eventually declared illegal by the World Trade Organisation in 2001 but at that time it had already been superseded by NAFTA.

${ }^{25}$ Canada-US Free Trade Agreement (FTA or CUSFTA) (1988) 27 International Legal Materials 293 [KJ5 I574].

${ }^{26}$ See Maureen Appeal Molot “The North American Free Trade Agreement: Policy or Investment-led?” in Richard G Lipsey and Patricio Meller, see above n 24.

27 Karla M Campbell "Guest Worker Programs and the Convergence of US Immigration \& Development Policies: A Two-Factor Economic Model” (2007) 21 Georgetown Immigration Law Journal 663.

28 United States-Canada Free Trade Agreement (1988) 27 International Legal Materials 281, at 368 [hereinafter FTA].

29 See James McIlroy “NAFTA Cross-border Provision of Services" (1996) 22 Canada-United States Law Journal 203, at 204. 
was a modest beginning: only three pages, plus annexes, relating to professions like architecture, tourism, computer services and telecommunications enhanced services. Anything not expressly included was excluded. $^{30}$

Thus, for example, health, education and social services were excluded. Afterwards, NAFTA expanded the list through the reworked provisions in Chapter 12 on Cross-Border Trade in Services. ${ }^{31}$

Services are a labour intensive sector. For example, it is not possible to envision free trade in architecture without allowing an architect at a minimum to survey the construction site. ${ }^{32}$ For this reason the drafters of the CUSFTA introduced Chapter Fifteen allowing the temporary entry of business persons as a corollary to Chapter Fourteen already permitting controlled labour mobility across the FTA member states and furnishing the mechanisms to facilitate such movements. ${ }^{33}$ It is true, of course, that labour issues in the CUSFTA raise far fewer concerns. No one was or is particularly worried about a flow of workers from Canada into the US or vice versa. This policy was replicated in Chapter Sixteen of NAFTA (Temporary Entry for Business Persons). ${ }^{34}$ Soon after the implementation of the Canada-US FTA on January 1, 1989, the US and Mexico began exploratory discussions on the possibility of entering into a free trade agreement. ${ }^{35}$ Canada quickly realised the potential impact of such an accord and the need to join it especially to make sure that Mexico would not end up with a more favourable agreement than Canada under the CUSFTA. Thus the negotiations for NAFTA were expanded to include Canada as well.

President George Bush requested from Congress fast track negotiating authority to expedite concluding an agreement. Moving rapidly to negotiate and approve the Treaty was depicted as necessary to avoid failure in reaching an agreement. NAFTA opponents objected to the quick pace of the negotiations and limiting the role of Congress on the matter to only an "up or down" vote. Limiting the debate and the input by Congress was seen by some

30 Ibid.

${ }^{31}$ See FTA, above n 26 at art 1501, 1502 S.

32 See Gal-Or, above n 3 , at 377.

33 See Howard F Chang "Liberalized Immigration as Free Trade: Economic Welfare and the Optimal Immigration Policy” (1997) 145 University of Pennsylvania Law Review 1147.

34 See Gal-Or, above n 3, at 371. See also Nancy Fuller-Jacobs “Labour Mobility and the North American Free Trade Agreement” (1993) 1 San Diego Justice Journal 289, at 290.

35 See G Hufbauer and J Schott North American Free Trade: Issues and Recommendations (Washington: Institute for International Economics, 1992). 
as undermining the democratic process. ${ }^{36}$ Labour and environmental organizations also opposed the fast track procedure ${ }^{37}$ as they perceived in NAFTA considerable threats to the environment and to labour standards. ${ }^{38}$ President Bush eventually succeeded in obtaining fast track authority but only on the condition of establishing a parallel negotiation track to deal with environmental and labour issues. ${ }^{39}$

Because of election campaign politics and the resonance among the American public of the criticism by environmental and labour groups, provisions favourable to the environment were moved from the parallel tract into NAFTA. ${ }^{40}$ Labour however did not achieve that level of success. ${ }^{41}$ While labour issues are mentioned in the list of NAFTA's goals contained in its Preamble, the Agreement does not address labour issues until Chapter Eight and then only indirectly in the emergency sections provisions. ${ }^{42}$ The responsibility of addressing those issues fell on President Clinton. It was done with two supplemental "side agreements," one on environment and one on labour. ${ }^{43}$ The considerable controversy about labour and the environment

${ }^{36}$ See Alan C Nelson “NAFTA: Immigration Issues Must Be Addressed” (1994) 27
UC Davis Law Review 987.

37 See Robert Housman "The Treatment of Labour and Environmental Issues in Future Western Hemisphere Trade Liberalisation Efforts” (1994) 10 Connecticut Journal of International Law 301, at 303.

${ }^{38}$ See Robert F Housman and Paul M Orbuch "Integrating Labour and Environmental Concerns into the North American Free Trade Agreement: A Look Back and a Look Ahead” (1993) 8 American Journal of International Law and Policy 719, at 724-25.

39 Ibid, at 719.

40 See Housman, above n 38, at 306-07.

${ }^{41}$ Elizabeth L Gunn “NOTE: Regionalizing Labour Policy Through NAFTA: Beyond President Bush's Temporary Worker Proposal” (2005) 28 Boston College International and Comparative Law Review 353.

42 See Kevin Johnson, above n 22, at 937. Johnson cites statements by the Bush administration to Congress: "Until it came time for Congress to consider whether to ratify the trade agreement, the anomaly of NAFTA's endorsement of free trade and closed borders went largely undiscussed, if not unnoticed...” at 941. See also Johnson's analysis of why immigration was excluded from the agenda: "because (a) the Bush administration's recognition of the political explosivity of the issue; (b) the closing of a vivid debate on immigration reform in the United States during the 1980s; (c) the diametrically opposed interests of the United States and Mexico regarding immigration potentially capable to undermine a trade treaty; and (d) Mexico’s repressed concern about American human rights violations during border enforcement, and America's fear that if discussed publicly it would lead to restrictions on their relevant policies.” See at 957-58.

${ }^{43}$ Unfortunately the two agreements did not harmonize the applicable laws across the NAFTA. See Housman, above n 38, at 306-07. 


\section{AN AMERICAN DILEMMA: THE FLOW OF TRADE VERSUS THE FLOW OF PEOPLE IN NAFTA}

revealed that all three Treaty Parties had already on the books well crafted laws to address the concerns of those opposing NAFTA on labour and environmental issues. ${ }^{44}$ Consequently, most of the criticism zeroed in on the non-existent movement of people.

The discussion in the United States relative to the ratification of NAFTA placed immigration front and centre as a key factor for both those supporting and opposing NAFTA. ${ }^{45}$ In the context of this debate, immigration from Canada into the United States at that time was not a problem. However, Mexican immigration into the United States was definitely a major concern. ${ }^{46}$ Those opposing NAFTA were very concerned that NAFTA would dramatically increase Mexican legal and illegal immigration into the US ${ }^{47}$ They lobbied for Congress to make ratification of NAFTA subject to a commitment on the part of Mexico to take aggressive steps to halt the flow of undocumented immigrants into the $\mathrm{US}^{48}$ On the other side of the border, prominent Mexican thinkers and writers, like Jorge Castaneda, criticized

\footnotetext{
${ }^{44}$ See Housman, above n 38, at 306-07.

45 Ibid.
}

${ }^{46}$ For the US, immigration from Canada in the late 1980s-early 1990s posed no threat and raised no concern, given the socio-economic similarities between the two countries and the ethnic and cultural background in common. The portion of Canadian and Mexican immigration into the US has changed considerably in the last 150 years. Canadian immigrants were more numerous for some 100 years, from the 1850s to the 1950s and peaked between 1921 and 1930 with a share of 22.5\%, declining since then. Both Canadian and Mexican immigration increased especially in the first part of the 20th century as the US grew more xenophobic and laws were passed excluding Asians (Chinese Exclusion 1882) and Southern-Eastern Europeans (National Origins quota system 1924). Canadian and Mexican immigration was stimulated especially during the two World Wars and the Great Depression when European immigration to the US was cut off by adverse war and economic conditions and restrictive laws. Since 1980 the share of immigrants from Canada has been steady at $2.1 \%$. Instead, the Mexican share, basically zero in the 19th century, has been growing exponentially especially since 1990 reaching about 25\%. This refers only to legal immigration. If one adds the undocumented immigrants, the Mexican share has been estimated at over $60 \%$. Thus, the "NAFTA share" (Canadian plus Mexican legal immigrants) reached a high of 35\% in 1920-1930, then declined and has been close to $25-26 \%$ for the last 20 years. See James F Hollifield and Thomas Osang "Trade and Migration in North America: The Role of NAFTA” (2005) 11 Law and Business Review of the Americas 327, at 335-36.

${ }^{47}$ See Gal-Or, above n 3, at 373. For recent data and trends on immigration to the US, see Jeffrey Passel and Roberto Suro Rise, Peak and Decline: Trends in US Immigration 1992-2004 (Pew Hispanic Center, September 2005).

48 See Melinda McGehee "Using Immigration as a Protectionist Mechanism while Promoting Free Trade” (2002) 8 Law and Business Review of the Americas 667. 
NAFTA for not allowing for labour mobility; ${ }^{49}$ Castaneda wrote: "The governments are opening borders for goods and capital flows, while labour, Mexico's main export, is barred from entry." 50

\section{NAFTA'S ADMINISTRATIVE REGULATIONS AND (LIMITED) IMMIGRATION OF WORKERS}

The NAFTA preamble states that the Parties have agreed to "protect, enhance and enforce basic workers' rights." ${ }^{, 51}$ However the right to seek work in another country was intentionally not included in the preamble,. ${ }^{52}$ While it would be a stretch to state that migration is a worker's right, increasingly, lack of development and economic opportunity is seen as the root of many serious violations of human rights affecting entire classes like women, indigenous people and minorities. Among the human rights violations are lack of access to education, career opportunities, health services, and participation in civil and economic society. ${ }^{53}$ The NAFTA preamble also lists the Parties' resolution to "create new employment opportunities, improve working conditions and living standards in their respective territories." 54 It is not evident if this applies to nationals of another Member Country. ${ }^{55}$ However, it is generally agreed that an unstated but significant objective of NAFTA is to create well paying jobs in Mexico so that Mexican workers, seeking work and to improve their lives, would not feel compelled any more to immigrate to the US undocumented. To address the issue at some level, the Agreement

49 See Kevin R Johnson, above n 22. See also Thomas M Fullerton and Richard L Sprinkle "Border Controls, Public Policy, Immigration, and Trade with Mexico" (2004) 10 Texas Hispanic Journal of Law and Policy 67.

50 See Jorge G Castaneda and Carlos Heredia "Another NAFTA: What a Good Agreement Should Offer” (1992) 9 World Policy Journal 673. See also Kevin Johnson "Race, the Immigration Laws, and Domestic Race Relations: A 'Magic Mirror' into the Heart of Darkness” (1998) 73 Indiana Law Journal 1111 and “An Essay on Immigration, Citizenship, and US/Mexico Relations: The Tale of Two Treaties” (1998) 5 Southwestern Journal of Law and Trade in the Americas 121.

${ }^{51}$ NAFTA, above $n 1$.

52 Jayashri Srikantiah "Globalization, Security \& Human Rights in the 21st Century” (2005) 16 Stanford Law and Policy Review 317.

53 These rights are routinely denied to their citizens by the States who are parties to the UN Covenant on Economic, Social and Cultural Rights. It is argued that States see these rights mostly as aspirational rather than "hard law". This is also the reason given by the US to refuse ratifying this Covenant.

54 Ibid.

55 See Teresa R Favilla-Solano "Legal Mechanisms for Enforcing Labour Rights Under NAFTA” (1996) 18 Hawaii Law Review 293. 
includes the right to employment and labour mobility in a limited way in two chapters, Chapter 12 on Cross Border Trade in Services and Chapter 16 on Temporary Entry for Business Persons. ${ }^{56}$ Chapter 12 provides the framework for mobility and the obligations related to services, especially professional services. ${ }^{57}$ Chapter 16 specifies who is eligible to take advantage of this mobility and how, by specifying the eligible professional services and the authorities in charge of them. ${ }^{58}$

Article 1213.2 defines professional services as "services, the provision of which requires specialized post-secondary education, or equivalent training or experience, and to which the right to practice is granted or restricted by a Party" but does not include services provided by trade persons or vessel and aircraft crew members. However, Chapter 12 unequivocally affirms that it does not create any immigration obligations for the Parties. In other words, it does not grant qualified citizens of the Parties the right to emigrate for employment. Article 1201.3 states:

"Nothing in this Chapter shall be construed to:

Impose any obligation on a Party with respect to a national of another Party seeking access to its employment market, or employed on a permanent basis in its territory, or to confer any right on that national with respect to such access or employment...,59

Chapter 16 relates to Chapter 12 since it is the chapter that most clearly deals with immigration issues. Article 1608 on Definitions, for example, defines temporary entry as:

“...entry into the territory of a Party by a business person of another Party without the intent to establish permanent residence." ${ }^{\circ 0}$

Additionally,

"Business person means a citizen of a Party who is engaged in the trade in goods, the provision of services or conduct of investment

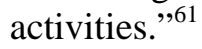

\footnotetext{
${ }^{56}$ NAFTA, above $\mathrm{n} 1$, at chs 12 and 16.

57 See James McIlroy “NAFTA Cross-Border Provision of Services” (1996) 222 Canada-United States Law Journal 203, at 204.

58 See above $n$ 57. The two chapters overlap somewhat. Chapter Sixteen cannot be implemented without compliance with chapter Twelve.

${ }^{59}$ NAFTA, above n 1 , at art 1201.3 .

${ }^{60}$ Ibid, at art 1608.
} 
The Annexes to Chapter 16 contain only eight articles. Article 1603, Section D on Professionals refers to those individuals practicing one of the professions listed in Schedule II. ${ }^{62}$ The list is quite narrow. Also, professionals from other NAFTA countries cannot be self-employed in the United States. ${ }^{63}$ The right of a Party to require a visa and to impose a quota is maintained. ${ }^{64}$ This has the effect of significantly limiting the liberalisation of mobility between the Parties covered in Section D, Article 2. ${ }^{65}$ The number of professionals allowed to enter the United States from Mexico has also been specifically limited to "5,500 initial petitions of business persons of Mexico seeking temporary entry under Section D of Article 1603."66 While Canadians also need work permits to come into the US to work, there is no numerical limit for Canadians. Thus, Mexican professionals are treated less favourably than Canadians. ${ }^{67}$ On the other hand, neither Canada nor Mexico has established quota limits on the entry of professionals from the other Parties. They do reserve the right to do so in the case of new members joining the NAFTA. $^{68}$

In conclusion, Chapter 16 neither permits immigration nor harmonizes the temporary entry conditions among the NAFTA Parties. Even when it comes to professionals listed on a restricted list, Chapter 16 does not allow for free and unrestricted temporary access. Among the three Parties, the United States provides the least favourable treatment. The Canadians have not obtained anything remarkably different under the NAFTA that they did not already have under the CUSFTA. The Mexicans continue to have the more limited

61 Ibid.

62 Ibid, at annex $1603 \mathrm{~S}$ D art 1.

63 See Gerald A Wunsch "Why NAFTA's Immigration Provisions Discriminate Against Mexican Nationals” (1994) 5 Indiana International and Comparative Law Review 127.

${ }^{64}$ See NAFTA, above $\mathrm{n} 1$, at annex $1603 \mathrm{~S} \mathrm{D}$ art 3.

${ }^{65}$ Ibid at annex 1603 S D arts 4-6. See Gal-Or, above n 3, at 376.

${ }^{66}$ This limitation will expire ten years from the entry into force of the NAFTA, unless the Parties agree to remove it earlier. See ibid at sched III, art 3(b).

67 See Ellen G Yost "NAFTA -- Temporary Entry Provisions -- Immigration Dimensions” (1996) 22 Canada-United States Law Journal 211, at 214.

68 See Yost, above n 68, at 219-20. On the contrary, as the United States fortifies its border with Mexico, Canadian companies are reaching out to immigrants who are frustrated by US restrictions and tempted by dreams of a better life in Canada. The Canadian government has been relaxing its immigration rules in an effort to attract students and skilled workers from all over the world. That, and the push by companies promising jobs and visas, is attracting Mexican professionals turned off by the Minuteman Project, new border walls, tougher US entry requirements and laws like Proposition 200 in Arizona. 


\section{AN AMERICAN DILEMMA: THE FLOW OF TRADE VERSUS THE FLOW OF PEOPLE IN NAFTA}

access to the United States than Canadians. While it is assumed that they are not that interested, US professionals also face limitations in their mobility to the other Parties. ${ }^{69}$ In other words, in contrast to the treaties among the 27 Member States of the European Union, ${ }^{70}$ NAFTA does not envision as one of its priorities the free movement of people across the (basically eliminated) national borders of its Parties on an equal and non-discriminatory basis like the EU does. ${ }^{71}$ Similarly, it does not grant them, once they cross a border, the right of establishment enjoyed by citizens of the European Union within the European Union. ${ }^{72}$

69 See Gal-Or, above n 3, at 381. For a summary of recent discussions on labour mobility, immigration and outsourcing, see Ryan Walters "Managing Global Mobility: Free Trade in Services in the Age of Terror" (2006) 6 UC Davis Law Review 92.

70 The most important treaties establishing what is today the European Union are: the Treaty of Rome (1957; Consolidated version, OJ C340 10.11.1997) establishing the original European Economic Community; the Single European Act (OJ L 169 of 29.06.1987); the Treaty on European Union or Maastricht Treaty (OJ C 191 of 29.07.1992) that created a European Union and granted citizenship of the European Union to every national of a Member State; the Treaty of Amsterdam (OJ C 340 of 10.11.1997); and the Treaty of Nice (OJ C 80 of 10.03.2001). A European Union Constitution (OJ C310 of 16.12.2004) is in the process of being adopted by the Member States but the likelihood of this happening appears to be remote at this time.

${ }^{71}$ See Karen Engle and William Powers "Working Borders: Linking Debates about Insourcing and Outsourcing of Capital and Labour” (2005) 40 Texas International Law Journal 691.

${ }^{72}$ Article 39 of the EC Treaty provides for free movement of workers. Initially these rights were given only to "economically active" people (workers and people looking for work) and their families. Gradually, it has been recognized that the free movement of workers includes a social dimension. Regulation 1612/68 establishes that free movement is a fundamental right of workers. Worker's rights include: the right to enter into any Member State, take up or search for employment; the right to reside; and the right to remain. The Treaty of European Union (1993) establishes European citizenship (Art 17). Every citizen of the Union has the right to move and reside freely within the territory of the Member States, subject to certain limitations and conditions (Art 18). Freedom of establishment goes beyond the right to take up an activity as a self-employed person. The European Court of Justice has held that it extends to other elements connected to that right eg the right to rent premises, equal treatment as regards housing, and a right to access leisure facilities on a non-discriminatory basis. Article 43 of the EC Treaty therefore prohibits both direct and indirect discrimination on nationality grounds. An important feature of the rights available under Article 43 is the fact that Member States cannot disregard qualifications obtained in another Member State. 


\section{LABOUR RELATED SUPPLEMENTARY AGREEMENTS}

Given the considerable limits to immigration even of professionals and the absence of any liberalisation for non-professionals, a side-agreement on labour, the North America Agreement on Labour Cooperation (NAALC), ${ }^{73}$ was negotiated and finalized one year after the NAFTA negotiations had been concluded. Along with the North American Agreement on Environmental Cooperation (NAAEC), ${ }^{74}$ NAALC is basically a supplement to the NAFTA. It does not amend the Agreement. The NAALC does not provide for an integration of labour markets and does not set rules for migratory labour. It is an agreement between the Parties to the NAFTA to maintain and enforce their own national domestic labour laws. It limits itself to formulating a legal procedure and to establishing a Commission on Labour Cooperation. There is also an arbitration clause, however this is yet to be invoked. ${ }^{75}$ The mission of the Commission is to monitor the conditions of the NAFTA labour market; to foster compliance with the national laws and regulations of the respective Parties; and to manage dispute settlements procedures.

In the United States, the NAALC ${ }^{76}$ was negotiated and proposed basically as a precondition to obtaining the ratification of the much debated NAFTA by

7332 ILM 1499 (1993) The NAALC was created to address labour issues among the three countries. It entered into force on January 1, 1994. Like the environmental side agreement, it encourages trilateral cooperation, and, through its Commission for Labour Cooperation (CLC), helps enforce existing domestic labour laws.

${ }^{74} 32$ ILM 1480 (1993) The NAAEC is the environmental side agreement to the NAFTA. It came into force January 1, 1994. The Agreement creates a framework to better conserve, protect and enhance the North American environment through cooperation and effective enforcement of environmental laws.

75 The Commission for Labour Cooperation is an international organisation created under the North American Agreement on Labour Cooperation (NAALC). The Commission is formed of a Council of Ministers, a cabinet-level body in charge of policy-setting and decision-making consisting of the three labour ministers or their representatives and a tri-national Secretariat that provides support to the Council and to the independent Evaluation Committees of Experts and Arbitral Panels the Council may establish under the provisions of the Agreement. The Commission works in close cooperation with the National Administrative Offices.

${ }^{76}$ Objectives of the NAALC: To improve working conditions and living standards in each Party's territory. To promote, to the maximum extent possible, the labour principles set out in the Agreement; to encourage cooperation to promote innovation and rising levels of productivity and quality; to encourage publication and exchange of information, data development and coordination, to carry out joint studies to enhance mutually beneficial understanding of the laws and institutions governing labour in each Party's territory; to pursue cooperative labour-related activities on the basis of mutual benefit, to promote compliance with, and effective enforcement by 
Congress. It was meant to control undocumented immigration between the United States and Mexico ${ }^{77}$ and to limit the migration of jobs and investment away from any of the Parties to the benefit of another Party, in this case Mexico. ${ }^{78}$ It does not cover at all the topic of labour mobility or labour standards. The provision for accession to the NAFTA itself ${ }^{79}$ does not include the NAALC since the NAALC was not concluded until about 9 months after NAFTA was signed and a year after completion of the NAFTA negotiations. ${ }^{80}$ This reminds us clearly of how the Parties have relegated labour to a tertiary concern, after trade and the environment. ${ }^{81}$

\section{TRADE, LABOUR STANDARDS AND MIGRATION: LINKS AND RELATIONSHIPS}

While one could argue that there is a strong link between the free movement of goods and services and the mobility of people involved in providing them, ${ }^{82}$ this inter-relationship has been overlooked, ignored or even rejected by those proposing free trade in North America. ${ }^{83}$ This is in line with most areas of the world using regional trade agreements, such as Mercosur and ASEAN, with the EU being a notable exception. On the other hand, the recognition of those links has been the hallmark of the European Union since

each Party of, its labour law; and to foster transparency in the administration of labour law. Source: http://www.naalc.org/english/objective.shtml

${ }^{77}$ See Johnson, above n 22, at 960.

${ }^{78}$ See Housman, above n 38, at 318.

${ }^{79}$ See NAFTA, above n 1, at art 2204. See Gal-Or, above n 3, at 383.

${ }^{80}$ This is not surprising given that the US didn't want to deal with migration issues at all. President Clinton's core labour union constituency had much less interest in promoting labour mobility than did President Bush I. Their professed objective was to force Mexico to comply with worker standards, given their concern that this lack of compliance depressed Mexican wages.

${ }^{81}$ One reason why the NAAEC is a bit stronger than the NAALC is that some environmental groups were willing to trade support of the NAFTA package for stronger environmental protections. The unions were not; they effectively told the Clinton Administration that they would continue to oppose NAFTA regardless of the content of the NAALC.

${ }^{82}$ Some might put it differently, noting that a principal purpose of free trade is to promote job growth in member countries so that workers there can find gainful employment, and not be forced, as a result, to migrate.

${ }^{83}$ See JoAnne D Spotts "US Immigration Policy on the Southwest Border from Reagan Through Clinton 1981-2001” (2002) 16 Georgetown Immigration Law Journal 601. 
its very beginning, even though implementation has been a "work in progress" over the last five decades. ${ }^{84}$

According to Elizabeth Kraus,

"The Bush administration, which negotiated the agreement, explained that an inclusive position, similar to that in the European Community (EC) [now European Union] is not necessary to the agreement as 'the fact of the matter is that what we are negotiating here is a trade agreement, not a social contract. We don't in NAFTA try to parallel the kinds of things which the EC, for instance, is engaged in with respect to political and social rights and that kind of things.",85

Experts, especially economists, are not of one mind when it comes to the linkages between social issues and free trade. ${ }^{86}$ The classical tenet is that growing trade boosts general welfare by reallocating resources, promoting specialization (the "comparative" advantage), and increasing production. That is what many experts, politicians, lobbyists and business leaders believed NAFTA would do for Mexico. The increased trade between the US and Mexico would have such a positive ripple effect on Mexico's economy that jobs would be created, the standard of living would grow rapidly, wealth would become widespread and thus immigration of Mexicans to the US would slow down to a trickle. Mexicans would remain in Mexico thanks to the prosperity brought by NAFTA, and the undocumented immigration problem would be solved. ${ }^{87}$

However, in a regional trade agreement like NAFTA or the EC, shortterm adjustment challenges invariably arise along with restructuring problems and the vicissitudes of local economic variables that cannot always be controlled very well. ${ }^{88}$ Ironically, at times, the opening of the borders to the growth of trade between vastly different and unequal economies can unleash serious problems and threaten disruptions in the economy, labour patterns,

\footnotetext{
${ }^{84}$ See Kraus, above n 8, at 325. See also Christopher J Cassise “The European Union $\mathrm{v}$ the United States under the NAFTA: A Comparative Analysis of the Free Movement of Persons Within the Regions” (1996) 46 Syracuse Law Review 1343, at 1372 and Craig L Jackson "Social Policy Harmonization and Worker Rights in the European Union: A Model for North America?” (1995) 21 North Carolina Journal of Commercial Law and International Regulation 1, at 14-15.

${ }^{85}$ See Kraus, above n 8, at 325.

86 Jagdeep S Bhandari “Migration and Trade Policies: Symmetry or Paradox?” (2007)

6 Journal of International Business and Law 17.

${ }^{87}$ See Philip Martin, above n 23, at 365.

88 See Ann Weston "Social Issues and Labour Adjustment Policies: The CanadaUnite States FTA Experience” in R Lipsey and P Meller, see above n 24.
} 
social life, patterns of consumption and cultural expectations of people, especially those in the less affluent and developed party. The widespread introduction of new technologies, the rapidly changing patterns of demand, the pressures of a quickly changing society oriented more and more on conspicuous consumption, and the ever increasing number and strength of competitors in the global sphere can challenge and deeply unsettle any given society. ${ }^{89}$ This has caused many, including free trade advocates, to realise that growth in trade and commercial integration cannot be isolated from considerations of social policy. ${ }^{90}$

However, few either in the US or Mexico really want to address social policy issues directly. One of the major reasons is that it is expensive. Another is that it requires a re-orientation of the mindset towards a more socially progressive or mildly "socialist" policy. The political struggle over the attempt by President Obama to address the lack of health care for 40 million Americans is a good example of these difficulties. The architects and builders of the European Union, which also began life as a free trade area, eventually recognized this. One of the mainstays of the EU have been the convergence and social cohesion funds that transfer considerable amounts of development assistance from wealthier Member States to less affluent ones to ensure their rapid growth and smoother transition from developing to relatively developed societies. The reasons are both historical and cultural, including but not limited to the concept of a social welfare state with a real safety net for the less fortunate citizens and nations. This approach has been reduced somewhat in the past 15 years because of increasing costs and diminishing revenues, due in part to an aging population, drastically reduced birth rates, and substantial job losses to cheaper labour areas, especially in Southeast Asia.

Initially Italy and then Greece, Spain, Portugal and Ireland have greatly benefited from this type of assistance. Now it is the turn of the newly admitted Eastern European Member States to receive this help, with the reluctant agreement of some of the former beneficiaries, especially Spain. ${ }^{91}$ The EU is likely unique in this respect. The NAFTA Parties weren't seeking anything like the level of integration that was contemplated for the EU, although Mexico likely would have welcomed it because it would be the NAFTA Member State benefiting the most from it. Even the other common markets that have tried to pattern themselves after the EU, such as Mercosur and ASEAN, have fallen far short with labour mobility as in most other areas. The

\footnotetext{
${ }^{89}$ See ibid. See also Gal-Or, above n 3, at 385.

${ }^{90}$ See ibid, at 192.

91 There are several types of funds used by the European Union to support the development of the "least favoured" regions, interregional cooperation, and making regions more competitive: Structural funds, cohesion funds, solidarity funds, ISPA, Phare, and Separd. See http://ec.europa.eu/regional_policy/index_en.htm
} 
uniqueness of the EU is that it was indeed eventually able to move towards a Single Europe in the late 1980s after a period of stagnation. ${ }^{92}$

\section{RECONCILING SOCIAL INTEGRATION AND REGIONAL FREE TRAD}

The awareness that the free movement of workers is ideally an integral part of free trade is slowly making some headway. ${ }^{93}$ It is possible, of course, to be concerned about social impacts without necessarily concluding that the solution is to encourage or permit migration to the wealthier parties. The EU's experience, however, supports equating recognition of the importance of the social impacts of FTAs with favouring a freer movement of people looking for work. As Ann Weston stated:

"There is growing consensus.... that for economic integration to be socially and politically sustainable, there must be greater attention paid to its social impact. This may lead to the conclusion that the process of trade liberalisation should be modified (in terms of the speed and scope as well as the underlying rules of the game) and/or that complementary amendments be made to social policies." ${ }^{94}$

One of the major obstacles to this approach is that in the prevailing capitalistic, neo-liberal model that governs production, trade and commerce in the US, labour is just another commodity and labour markets are supposed to behave just like any other market. ${ }^{95}$ There are signs that President Obama would like to change this approach but it is unclear whether he will have any success. Thus, it is difficult to sustain a political effort that would recognize the free movement of workers as a fundamental right of all those residing in NAFTA countries. While it is becoming more recognized that trade and

\footnotetext{
92 The Single European Act (SEA) was the first major revision of the 1957 Treaty of Rome. The Act set for the European Community the objective of establishing a Common Market by 31 December 1992, and codified European Political Cooperation, the forerunner of the European Union's Common Foreign and Security Policy. It came into effect on 1 July 1987. The Act's signing grew from the discontent among European Community members in the 1980s about the de facto lack of free trade among them.

Eur-lex.europa.eu/en/treaties/dat/111986U/tif/JOL_1987_169_EN_0002.tif

93 Jagdeep S Bhandari "International Migration and Trade: A Multidisciplinary Synthesis” (2006) 6 Richmond Journal of Global Law and Business 113.

${ }^{94}$ See Ann Weston, above n 90, at 192.

95 Ian Robinson “The NAFTA Labour Accord in Canada: Experience, Prospects, and Alternatives” (1994) 10 Connecticut Journal of International Law 475, at 488.
} 
labour mobility are linked, ${ }^{96}$ there is reluctance to deepen the discourse to include, for example, under what conditions there could be labour mobility between the US and Mexico, for example or to take into consideration the need to agree on labour standards. ${ }^{97}$ There have been some efforts here but US and Canadian labour interests feel that common standards would have a "least common denominator" effect, resulting in looser labour standards in the US and Canada.

Three major approaches to this area have been recognized and labelled as the NAFTA Clean Approach, the NAFTA Plus Approach and the NAFTA Package Approach. ${ }^{98}$

Those who advance the NAFTA Clean Approach consider the links between labour and trade not that strong or self-evident. Thus, NAFTA should not take labour issues into serious consideration.

The proponents of the NAFTA Plus Approach are at the opposite end of the continuum. ${ }^{99}$ Labour rights and environmental protection supporters want NAFTA to recognize the essential importance of the link between trade and labour and to include strong and enforceable clauses to address it. This should be done also in preparation for a possible deepening of NAFTA. The growth of China, India, and Brazil especially may make it not only attractive but necessary for their survival for the NAFTA countries to consider moving forward with a deeper union, going beyond being only an FTA in order to be competitive, face jointly threats originating especially in Asia, and survive. The creation and implementation of provisions protecting labour and the environment and the creation of a strong mechanism to address labour, environment and trade-related problems and disputes are considered indispensable for the orderly and successful deepening of NAFTA and for its eventual expansion. ${ }^{100}$

It must be recognized that there are nuances in all of this. Not all those seeking recognition of these links are interested in encouraging immigration. They may actually want the opposite, which is the creation of more jobs and

96 Bill Ong Hing “NAFTA, Globalization and Mexican Migrants” (2009) 5 Journal of Law Economics and Policy 87.

97 Bill Ong Hing “Immigration Policy: Thinking Outside the (Big) Box” (2007) 39 Connecticut Law Review 1401.

98 See Housman, above n 38, at 306-07. The trans-border issue covers undocumented migration, social dumping across the border and labour and environmental standards in the maquiladoras, immigration enforcement and related smuggling, trafficking and violence, etc. See also Amanda E Schreyer, "Human Smuggling Across the USMexico Border: US Laws Are not Stopping it” (2006) 39 Suffolk University Law Review 793.

${ }^{99}$ Ibid, at 319.

${ }^{100}$ Ibid, at 321-22. 
labour rights in Mexico, to keep additional Mexican immigrants home. The theory here is that a labour surplus would depress wage rates in the US. However, this is not necessarily so. The opposite can also happen, as the EU's experience demonstrates. The free movement of people in the EU has not necessarily or significantly depressed wages in the wealthier EU countries. ${ }^{101}$ On the contrary, it has increased wages in the poorer ones to the point that some international companies, including American ones, that established factories in Eastern Europe, are already moving them out of there because labour has become too costly in just a few years.

The NAFTA Package Approach includes the NAFTA, the NAALC and the NAAEC. It is the compromise approach attempting to mesh labour and environmental issues with free trade interests. ${ }^{102}$ It would require new Member Countries to adopt the entire package, just as the EU requires new Member States to accept the so-called acquis communautaire ${ }^{103}$ and enforce existing laws and regulations accordingly. ${ }^{104}$ This is in consonance with what occurs now with the U S FTAs agreements subsequent to NAFTA. The labour and environmental provisions are part of the FTA, not side agreements, and are subject to the regular government to government dispute settlement mechanisms.

One could argue that action is needed especially since the NAFTA, while addressing the restricted migration of professional directly, leaves out the low-skill and low-income sector. ${ }^{105}$ Yet it is specifically that sector that presents the biggest undocumented immigration challenge to the United States, while at the same time former President George W. Bush, countless politicians and many business leaders have constantly stressed how much the

101 Notwithstanding the well-known "Polish plumber" debate in Germany where some people, especially plumbers, argued that day immigrants from nearby lowerwage countries were forcing down blue collar earnings by unfairly competing with local labour by means of charging considerably less for their services.

102 Ibid, at 323. See also Gal-Or, above n 3, at 387.

103 The French term acquis communautaire is used in European Union law to refer to the total body of EU law accumulated so far. During the process of the enlargement of the European Union, the acquis is divided into 31 chapters for the purpose of negotiation between the EU and the candidate member states.

${ }^{104}$ For a good comparison of the EU and NAFTA and an assessment of NAFTA in comparison with the EU, see M Jeannette Yakamavich "NAFTA on the Move: the United States and Mexico on a Journey Toward the Free Movement of Workers: A NAFTA Progress Report and EU Comparison” (2002) 8 Law and Business Review Annuals 463. For an analysis of Mexican President Fox's vision of NAFTA becoming like the EU, see Jennifer E Harman "Mexican President Vicente Fox's Proposal to Expand NAFTA into a European Union-Style Common Market: Obstacles and Outlook” (2001) 7 Law and Business Review Annuals 207.

105 See Molot, above n 27, at 171. See also Gal-Or, above n 3, at 391. 


\section{AN AMERICAN DILEMMA: THE FLOW OF TRADE VERSUS THE FLOW OF PEOPLE IN NAFTA}

U S economy needs and benefits from low skills workers typically believed to do jobs that Americans do not want any more. ${ }^{106}$ That was the main stated rationale that propelled, for example, the 2008 proposals by the George W Bush White House to create a guest worker programme. ${ }^{107}$

While it may be true that most of those concerned with the weak treatment of labour issues under NAFTA are not interested in promoting migration, documented and undocumented migration continues unabated and is growing within NAFTA and worldwide. ${ }^{108}$ Moreover, we have come to realise that trafficking in human beings is a very large and lucrative business and one of the most shameful phenomena that characterise globalisation. ${ }^{109}$ To continue arguing that creating better jobs in Mexico (or other countries) will keep would-be immigrants home is simply not working, especially in light of the fact that the relatively better jobs that the "maquiladoras" offered Mexicans in border towns with the U S have significantly diminished. Quite a few of the "maquiladoras"110 built with great hopes of improving the Mexican economy, creating large employment and keeping Mexicans in Mexico, are now closed, ${ }^{111}$ the jobs gone to China and other even cheaper countries in South

${ }^{106}$ The ambivalent and opportunistic policy and enforcement of the immigration laws by the current administration is illustrated by the fact that in 1999, under President Bill Clinton, the US government collected \$3.69 million in fines from 890 companies for employing undocumented workers. In 2004, under President George Bush, the federal government collected $\$ 188,500$ from 64 companies for such illegal employment practices. And in 2004, the Bush Administration levied no fines for US companies employing undocumented workers. The penalty exacted under the Bush White House was quite inconsequential for most medium and large businesses (an average of \$41,460 under the Clinton administration and \$2,945 under the Bush administration). http://usliberals.about.com/od/immigration/a/IllegalImmi_2.htm

107 See Michael J Mayerl "Proposed Guest Worker Statutes: An Unsatisfactory Answer to a Difficult, if not Impossible, Question” (2002) 6 Journal of Small and Emerging Business 559.

108 Teresa A Miller "A New Look at Neo-Liberal Economic Policies and the Criminalization of Undocumented Migration” (2008)61 SMU Law Review 171.

${ }^{109}$ www.state.gov/g/tip/rls/tiprpt/2009.

${ }^{110}$ At one point, there were more than 2,700 maquiladoras in Mexican Border States. Presently, it is estimated that there are 2,000 maquilas plants still in business, with employment probably around 800,000. Maquiladoras (export-oriented factories) on the border account for about 71 percent of all such factories in Mexico. The maquiladora industry is the major legal source of Mexico's export earnings. http://www.migrationinformation.org/Feature/display.cfm?ID=407

${ }^{111}$ It has been reported that more than 500 plants have closed since the beginning of the decade, causing a loss of several hundred thousand jobs. China is bolstering its status as the world's cheap assembly export location. http://geography.about.com/od/urbaneconomicgeography/a/maquiladoras.htm 
Asia. ${ }^{112}$ The economic crisis impacting much of the manufacturing world has affected Mexico as well. Those reputedly better paying jobs are simply not materializing or having a long life and the migration continues unabated. ${ }^{113}$ Studying more closely the EU experience and overcoming certain fears and prejudices, including plain racism ${ }^{114}$ as well as economic fears, may be needed for the U S to continue to be competitive and survive the onslaught of Chinese and other growing countries' manufactured goods. ${ }^{115}$ Mexico has also been seriously impacted by cheap Chinese imports, for example in the footwear, consumer electronics and textile/clothing sectors. Thus there is a common interest in deepening the NAFTA in order to effectively counteract negative trade developments and survive, learning from and following the EU's experience.

A growing Mexican immigration into the United States cannot be stopped $^{116}$ even though U S policy makers will continue trying, if not to stop

112 Federal Reserve Bank of Dallas, Beyond the Border: Have Mexico Maquiladoras Bottomed Out? Southwest Economy, Issue 1, Jan/Feb 2004.

${ }^{113}$ Ranko Shiraki Oliver "In the Twelve Years of NAFTA, the Treaty Gave to Me ... What, Exactly?: An Assessment of Economic, Social, and Political Developments in Mexico since 1994 and Their Impact on Mexican Immigration into the United States” (2007) 10 Harvard Latino Law Review 53.

114 ESSAY: “Aliens” in Our Midst Post-9/11: Legislating Outsiderness within the Borders, Defining America Through Immigration Policy (Mapping Racisms Series). The "Huddled Masses" Myth: Immigration and Civil Rights. By Kevin R Johnson, Reviewed by Raquel Aldana \& Sylvia R Lazos Vargas.

115 It depends naturally on who one is talking to. One could argue that US competitiveness with China would be most enhanced if Mexican production by US firms were increased so that only parts and components are made in the US The argument is that there is no effective means of dealing with high US wages in some industries.

116 The total number of Mexicans in the US, according to the Pew Hispanic Center mid-decade estimate, is almost 27 million. Mexicans constitute $64 \%$ of all Hispanics in the United States and $30.7 \%$ of all foreign born in the United States, by far the largest Hispanic group and $9 \%$ of the overall United States population, the third largest ethnic group after Whites and Blacks (all Hispanics are the second largest group at 14.5\%). The United States issued 906,622 non-immigrant visas for Mexicans in fiscal year (FY) 2005. In addition, 732,566 laser visas (which replaced the old border crossing cards for those who live on the Mexican side of the border but work in the United States) were issued in FY 2005. As of March 2006, the estimated unauthorized population in the United States was 11.5 to 12 million, of which 4.5 to 6 million entered legally with inspection and 6 to 7 million entered illegally without inspection. An estimated 6.2 million (or 56 percent) of all unauthorized migrants are from Mexico. (Sources: Pew Hispanic Center Estimates based on March 2005 Current Population Survey; DHS reports;

http://www.migrationinformation.org/Feature/display.cfm?ID=407). 


\section{AN AMERICAN DILEMMA: THE FLOW OF TRADE VERSUS THE FLOW OF PEOPLE IN NAFTA}

it, at least to slow it down. A critical mass of the Mexican-American population has been reached. ${ }^{117}$ Ties between Mexicans and their family members in the United States, the geographical land connection between the US and Mexico which facilitates traveling back and forth between the two countries and maintains strong affective, language and cultural ties with the place of origin, and the relative ease of travel in today's high mobility world ${ }^{118}$ make possible, support and spur the constant flow of migrants to the US and make the need to integrate into the host society less urgent and necessary. ${ }^{119}$ Promoting economic development in Mexico, thus providing economic incentives for Mexicans not to leave, has been proposed as an outcome of NAFTA and as the justification to ignore migration issues. ${ }^{120}$ However, the US has never made a real, serious effort to foster such development like the European Investment Bank ${ }^{121}$ in Luxembourg or the European Bank for Reconstruction and Development ${ }^{122}$ in London have done,

117 Marc Belanger "Immigration, Race, and Economic Globalization on the USMexico Border: Tangled Histories and Contemporary Realities” (2006) 10 Journal of Gender Race and Justice 1.

118 Even though it has become more difficult to cross the border successfully into the US, with obstacles like the fence built by the US, military air patrols, death in the desert, unscrupulous coyotes, the high cost of paying coyotes as a guide into the United States, etc.

${ }^{119}$ It is estimated that there are between 8 and 10 million undocumented workers in the US. For a discussion of employer sanctions as a way to discourage undocumented immigration, see Jeffrey L Ehrenpreis “Controlling Our Borders Through Enhanced Employer Sanctions” (2006) 79 Southern California Law Review 1203. See also Daniel A Scharf "For Humane Borders: Two Decades of Death and Illegal Activity in the Sonoran Desert” (2006) 38 Case Western Journal of International Law 141.

120 Carvana Hicks "The NAFTA Aftermath: Analyzing a Free Trade Agreement Defectively Designed to Perpetuate Poverty and Dependency in Rural Mexico" (2004) 13 Currents International Trade Law Journal 49, at 51.

121 The European Investment Bank (Banque Européenne d'Investissement) is the European Union's long-term lending institution established in 1958 under the Treaty of Rome. A policy-driven bank, the EIB supports the EU's priority objectives, especially European integration and the development of economically weak regions. Recently, the Bank has also been actively supporting European R\&D projects as part of EU's objective of building the world's leading knowledge-based economy.

122 Founded in 1991, the European Bank for Reconstruction and Development (EBRD) uses investment to help build market economies and democracies in 30 countries from central Europe to central Asia. Its mission initially was to support Europe's formerly communist countries in the process of establishing their own free market economies. For this reason, despite its public sector shareholders, it invests mainly in private enterprises, usually together with commercial partners. EBRD provides project financing for banks, industries and businesses, both new ventures and investments in existing companies. It also works with publicly owned companies to 
especially for Southern and Eastern Europe. Moreover, as already stated, Mexico has suffered considerable economic contraction because of the direct competition of Chinese imports, which are cheaper than locally produced goods. Thus, the migratory pressure will continue and increase. ${ }^{123}$

A truly different and forward-looking alternative would be to permit freer legal migration, recognizing and accepting that social and economic forces will continue to provide a strong impetus for migration between Mexico and the $\mathrm{US}^{124}$ The issue is, of course, job creation. Traditionally the US government has not been willing to devote sufficient resources to this end. However, the dramatic and profound economic crisis of 2009 has forced a change in the role that government plays in the US labour market. There is tremendous pressure on the Obama administration to address the unemployment crisis, officially at just below $10 \%$ nationwide at the end of 2009 but in reality around $18 \%$ or more. The massive governmental intervention to save and stabilize the economy, especially the stock market, banks, insurance and automotive sectors, has altered the relation between the U S government and the U S economy, industry and people. The health care reform, especially if a public option is successfully included, is also a powerful and undeniable indication of the major role that the government is taking in the ordinary lives of Americans. While the U S is not becoming any time soon a "State Providence" that provides for its citizens from the cradle to the grave as in Europe, particularly in Scandinavian countries, one can argue with considerable strength that the classic and mythical "self help" model of Americans, solving their own problems without the government's intervention, is pretty mythical, at best a relic of an XVIII century farming and ranching society where circumstances and lifestyle made self-help often the only available solution to life's problems.

The EU opening of the frontiers of the more affluent countries to the free circulation of "poorer cousins" first from the South (Italy, Greece), then the Southwest (Spain, Portugal), and most recently the East (Poland and other former Eastern Soviet block countries) of Europe can serve as a model, ${ }^{125}$ if

support privatisation, restructuring state-owned firms and improvement of municipal services. The EBRD's mandate stipulates that it must only work in countries that are committed to democratic principles.

123 “Border-Crossing Deaths Have Doubled Since 1995; Border Patrol's Efforts to Prevent Deaths Have Not Been Fully Evaluated” (PDF). Government Accountability Office, August 2006, p 42. http://www.gao.gov/new.items/d06770.pdf.

124 Philip I Martin "Economic Integration and Migration: The Case of NAFTA" (1999) 3 UCLA Journal of International Law and Foreign Affairs 419, at 423.

125 See Christopher Cassise "The European Union v the United States Under the NAFTA: A Comparative Analysis of the Free Movement of Persons Within the Region” (1996) 46 Syracuse Law Review 1343. 
and when the US is prepared to foster a "wider and deeper" NAFTA, which does not seem very likely in the short or medium term. However, the world has changed dramatically just in the last year as the bowing of President Obama to Japan's Emperor, a gesture widely criticized, his praiseful and subdued statements about China vis-à-vis the U S and the decline of the dollar clearly (and painfully) indicate. ${ }^{126}$ While it is easier to move U S factories to Mexico, China, or Vietnam, given the zero or low tariffs on most imported goods other than textiles and clothing, there is a long term high price to be paid for the gradual but inevitable loss of technical know-how and manufacturing innovation and for the loss of employment that affects not only individuals and their families but their entire communities as well. An amendment to NAFTA dealing with the integration of the regional movement of labour, including Americans working in Mexico, would be groundbreaking. ${ }^{127}$ While President Obama was focused, when advocating NAFTA amendments in his campaign in 2008, on improving the enforcement of the labour and environmental obligations vis-a-vis Mexico, and never suggested amendments relating to migration, events in the world, and especially the US economy, may force his and Congress's hand on this. To his credit, the administration has announced a new effort to convince Congress to enact immigration reform in a manner that would deal reasonably with the 12 million undocumented aliens now in the US. One does not need to be overly pessimistic to know that such measure would be nothing more than a band-aid, a stopgap in a continuing migratory march towards richer countries worldwide.

The best solution would be to move NAFTA beyond being merely a free trade area and eventually, long term, progress through various steps to become more and more like the EU. For instance, NAFTA should move from being simply a FTA to becoming a customs union, then to having a joint economic and monetary policy, then to further legal and economic harmonization, the formulation of a common security and immigration policy, and finally reaching political integration and adopting a common foreign policy. ${ }^{128}$ This would require that all three NAFTA members, but especially Mexico, make a broad variety of legal, economic, tax and policy changes.

\footnotetext{
126 See Kevin R Johnson "Regional Integration in North America and Europe: Lessons About Civil Rights and Equal Citizenship” (2001) 9 University of Miami International and Comparative Law Review 33 (2001).

127 Elizabeth L Gunn "Regionalizing Labour Policy through NAFTA: Beyond President Bush's Temporary Worker Proposal” (2005) 28 Boston College International and Comparative Law Review 353, at 369.

128 Stephen Zamora “A Proposed North American Regional Development Fund: The Next Phase of North American Integration under NAFTA” (2008) 40 Loyola University Chicago Law Journal 93.
} 
Mexico was already forced to make some changes with NAFTA but not in terms of rule of law, tax and energy policies, etc. Obviously, the US economy, even in boom times, ${ }^{129}$ could not possibly absorb the 40-50 million Mexicans (and additional Central Americans traveling to the US through Mexico) that some estimate would move or attempt to move to the U S, if given the chance. Thus, adopting the four EU's freedoms as the basic law of NAFTA: freedom of movement of capital, goods, services and people ${ }^{130}$ would require a considerable evolution of NAFTA over a number of years. A factor working in favor of a deeper union is the eventual slowing down in Mexico's population growth, reducing the labour pool ready to emigrate.

Whether the politicians and the voters in the US will acknowledge and accept that a Mexican presence in this country is inevitable and unstoppable is not all certain at this point, especially in the post 9/11 and current economic crisis environment. ${ }^{131}$ However, Americans may have to come to accept that fundamental equations of power have been and are changing in the world and that the days of the U S unfettered, unchallenged and single-handed preeminence and dominance in the world, especially in the world's economy, are counted. The EU adopted the four freedoms and implemented them over a 50 -year time period, at times with tremendous resistance, because of the realization that not doing so would mark the end of Europe's way of life and wealth. It is argued here that there are strong enough indicators to support an eventual expansion of NAFTA to include the free movement of people (workers) as a long-term objective and as part of a deeper and broader regional integration, which also presupposes substantial reforms, especially in Mexico. Not doing so will be at the future's peril of the US.

129 Gordon H Hanson, Kenneth Scheve, Matthew J Slaughter, and Antonio Spilimbergo (May 2001), Immigration and the US Economy: Labour-Market Impacts, Illegal Entry and Policy Choices, retrieved 2008-04-18, http://papers.ssrn.com/sol3/papers.cfm?abstract_id=296108;

130 Dara Cox Bachman "Forget NAFTA: How the US Can Obtain Improved Protection of Copyrighted Goods in Mexico Through the Creation of An Open United States-Mexico Border” (2005) 24 Pennsylvania State International Law Review 427.

131 For a guarded view of the future of NAFTA post 9/11, see Lisa J Bauer “The Effect of Post 9/11 Border Security Provisions on Mexicans Working in the United States: An End to Free Trade?” (2004) 18 Emory International Law Review 725. See also Hale E Sheppard "Salvaging Trade, Economic and Political Relations with Mexico in the Aftermath of the Terrorist Attacks: A Call for a Re-evaluation of US Law and Policy” (2002) 20 Boston University International Law Journal 33. 